\title{
天空率と天空比との関係に関する考察 \\ THEORETICAL ANALYSIS OF SKY EXPOSURE CRITERION
}

\author{
蓮香文絵*1, 大澤義明*2, 切田 元*3, 小林隆 史*4 \\ Fumie HASUKA, Yoshiaki OHSAWA, Hajime KIRITA \\ and Takafumi KOBA YASHI
}

\begin{abstract}
The purpose of the paper is to analyze theoretically the sky factor with the sky amount as sky exposure criterion, using a three-dimensional spatial model. First, we demonstrate that the sky factor is always greater than the sky amount for any shape of building. Second, we prove that the difference between the sky factor and the sky amount is maximum when the angle of elevation is between $30^{\circ}$ and $40^{\circ}$, measured at the center of the building. Finally, we show that the difference is bounded by $11 \%$ for any rectangular parallelopiped.
\end{abstract}

\footnotetext{
Keywords: sky factor, sky amount, building standard law, solid angles, proportion of street 天空率, 天空比, 建築基準法, 立体角, 街路プロポーション
}

\section{1 背景と目的}

2003 年 1 月 1 日，改正建築基準法が施行され，新たに天空率に よる斜線制限緩和制度が設けられた。一般に, 天空率規制と呼ばれ るものである122)．ある一定の天空率を満たしていれば，斜線制限 に適合しない建筑物でも建築可能となり，斜線制限に換わる性能規 定という位置付けになる. そのため, 天空率規制を採用した建築物 が急增しており，都市景観が大きく変貌しようとしている.

天空率は，通風・採光の度合いを指標化するのが役割である（建 築基淮法施行令第 135 条の 5 関保)．四 1 のように，天空率は， 半球（測定半球と呼ばれる2)）表面に投影された空及び建物を，地 表面（天空面と呼ばれる2)）へ正射影しその射影面上での空比率を 計測する. そのため, 球面表面積で測定される空比率，つまり，天 空比とは一致しない(3)4)5)6)。 天空率や天空比は立体角之強く関連 する. 天空比は立体角に比例し，天空率は立体角に余弦法則を適用 して得られる778). 天空が等輝度完全拡散光源面であると仮定する と, 天空率は水平面での明るさを表す，一方，天空比は，建物から 受ける圧迫感と関連し，心理的な開放感と比例する数值だと言われ ている4).このように, 天空率と天空比は採光や開放性の代表的指 標である゙)

計算方法や指標目的を考えるとここれらの指標はある程度相関す ることが予想される. 実際多くの文献で，天空率と天空比とが並べ
て説明されている34)5)699). したがって，天空率規制が導入され， 天空率が重要な環境指標となりつつある現在, その天空率がぞの程 度天空比を保証するのかは興味ある話題である. また，天空率規制 が通風や採光確保を目指しているのであれば，水平という受光面で の測定結果だけで判断して良いのかという素朴な疑問が生じる。例 えば，通風を考えると鈶直方向の風よりは水平方向の風の方が望ま しい．天空の受光面として，壁を想定することもあり得るだろうか ら, 受光面をすべての方向へ回転させたときの直接昼光率の平均で もある天空比という情報も有用かもしれない.

本研究の目的は, どのような建物形状で天空率と天空比とが渄離 するのかを，建物への仰角，水平角，測定位置の点から分析するこ とにある. 最初に，形状を特定しない建物に対しての知見を導出す る. 次に, 简潔で理解しやすい状況として, 道路沿いの直方体建物 を考光，幅員，建物高さ，建物長さといった街路プロポーションが 天空率と天空比との差へ与える影響について分析する. なお，本研 究では解析的結果を導出する. 天空率算定図 ${ }^{5}$ や面積測定等による 近似計算や実測を用いないので，算定点分布や計測方法に依存しな い安定した結果が得られる.

天空率に関する論文として，例えば，東京都内やロンドン, パリ の掫影写真から天空率を実測した研究 ${ }^{10) 11)}$ ，仮想市街地での平均

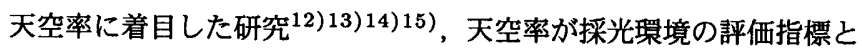

*1 三井情報開発 修士(環境科学)

*2 筑波大学社会工学系 教授 - 学博

*3 筑波大学システム情報工学研究科 大学院生・学士 (社会工学)

*4 筑波大学システム情報工学研究科 大学院生・修士 (社会工学)
Mitsui Knowledge Industry, M. of Environmental Sciences

Prof., University of Tsukuba, Ph. D.

Graduate Student, University of Tsukuba

Graduate Student, University of Tsukuba, M. of Policy and Planning Sciences 
して適切かどうかを検討した研究16)17)18)19)などがある. 天空率研 究を概観した論文 ${ }^{19)}$ もある. また，天空比計算に必要な立体角に関 する研究7)8)20)21), 球面での分析結果と平面での分析結果との乘離 を扱った分析 ${ }^{22)}$ もある. しかし，著者らが知る限りでは，天空率と 天空比とがどのように異なるかは必ずしも明確にはなっていない. しかも, 天空率や天空比を扱うほとんどの研究が, 実測や数值計算 で知見を導出しており，解析的研究はほとんど無い．本研究では， 天空率と天空比との関係を解析的に分析することに主眼を置く.

なお, 天空率も天空比も相対量である. そこで, 本研究では両者 を文中では 0 から 1 までの比率で, 図表ではパーセントにて表現 する.

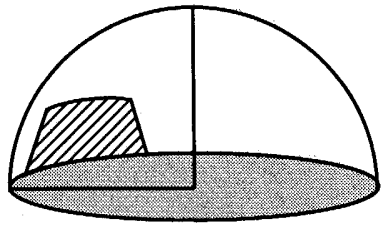

球面

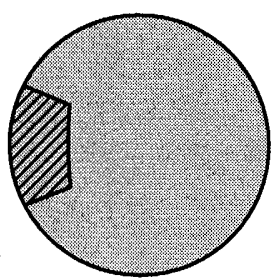

建築基準法の天空表示
図 1 建築基準法の天空表示

\section{2 一般建物での評価}

\section{1 大小関係}

平坦な土地に直立する建物を考える．この場合，どの位置で測定 したとしても, 天空率は天空比より常に高い值をとる.

命題 1 天空率 $\sigma$ は天空比 $\omega$ より大きい.つまり,

$$
\sigma>\omega
$$

証明： 天空率や天空比は表面積の相対的比率を表すので, 想定半 球が単位半球（半径が 1 の球）としても一般性は失われない，建物 は地面から直立しているので, 図 2 に示した濃い陰影部分のように 想定球面を地表面と二つの子午線から構成される微小球面三角形て 分割することを考える.すると，各微小球面三角形では，ある角度 から定まる距等圈にて建物投影部分と空投影部分とに二分割される. そこで, 微小球面三角形で空投影部分が占める表面積の割合が，こ の球面三角形の正射影において空投影部分が占める面積割合とを比 較し，後者が必ず高いことを証明する.

比例関係から, 微小球面三角形での議論は球帽での議論と等価で ある.したがって，球帽での天空率と天空比とを比較する．まずは， 球帽の天空比 $\omega$ を求める. 図 2 に示された斜線陰影部分のように角 度 $\rho$ で定義される単位球帽の表面積は, $2 \pi(1-\cos \rho)$ となる $\left.{ }^{23}\right)$. 半球表面積（底面積を除く）は $2 \pi$ であるから, 天空比 $\omega$ は,

$$
\omega=\frac{2 \pi(1-\cos \rho)}{2 \pi}=1-\cos \rho .
$$

次に, 天空率 $\sigma$ を求める. 図 2 の球帽を天空面へ正射影すると, 円となる. その円の半径は $\sin \rho$ であるので, 天空率 $\sigma$ は,

$$
\sigma=\frac{\pi \sin ^{2} \rho}{\pi}=\sin ^{2} \rho=1-\cos ^{2} \rho .
$$

$\cos \rho>\cos ^{2} \rho$ なので, 式 (1) と式 (2) との比較から, $\omega<\sigma$ とな る.

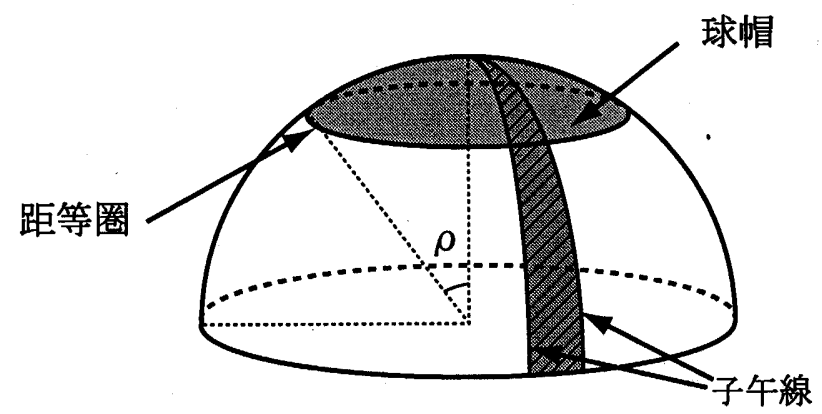

図 2 球帽, 微小球面三角形

命題 1 から，天空率は天空比の上限値を，逆に，天空比は天空率 の下限値を与えていることが分かる.この結果は，天空率算定図か ら求めた天空率と天空比との比較結果 ${ }^{4) 5(6) 20)}$ と整合する.

この大小関係は, 明らかである. 水平面の明るさは天頂部分の天 空が最も有利であり, 地平線に近い天空からの頁献は少ない。地面 から直立する建物は水平面の明るさに貢献しない地平線に近い天空 を遮断することとなり，天空比を小さくするが，天空率を大きく削 減しない，実際，天空率や天空比の算定図を比較すると，天空率計 算の点分布は天空比計算の点分布より全体が中心に位圈している5). そのため, 地上部から立ち上がる建物と重なる点の数は, 天空率計 算の点分布の方が少ないのである.

この関係は，正射影という視点からも説明できる. 図 3 は一つの アーチ天空を正射影したものである．同じ長さの円弧ではあるが， 仰角が浅くなるにつれて投影部分の長さは $c>b>a$ と短くなる.

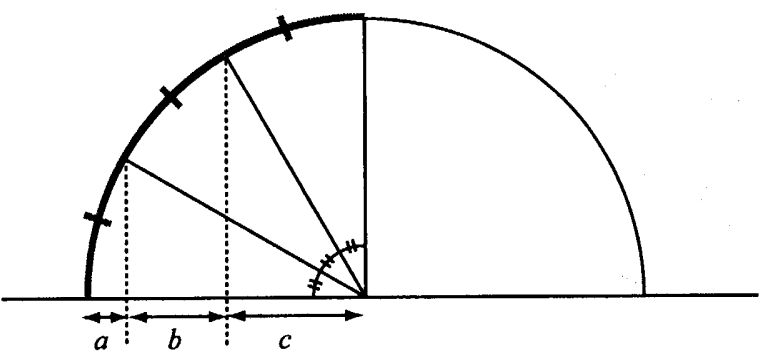

図 3 大小関倸の説明

\section{2 最大差}

両指標の差はどの程度まで広がるであろうか. 天空率と天空比と の差に関して, 次の上限値がある.

命題 2 最大差は 0.25 である.つまり,

$$
|\sigma-\omega| \leq 0.25
$$

証明 : 測定半球を構成するすべての微小球面三角形ごとに差が最大 となれば, 測定半径での差も最大となる. 従って, 差が最大となる 建物の天空部分は，球帽にならなければならない， $\rho$ の補角である 仰角を $\alpha \equiv \frac{\pi}{2}-\rho$ とする. 式 (1) と式 (2) から, 天空率と天空比 との差 $f(\alpha) \equiv \sigma-\omega$ は，どの方角も仰角が同一なので，

$f(\alpha)=\cos \left(\frac{\pi}{2}-\alpha\right)-\cos ^{2}\left(\frac{\pi}{2}-\alpha\right)=\sin \alpha(1-\sin \alpha)$.

$f(\alpha)$ の角度 $\alpha$ に関する導関数は，

$$
\frac{\mathrm{d}}{\mathrm{d} \alpha} f(\alpha)=\cos \alpha(1-2 \sin \alpha) .
$$


よって, $f(\alpha)$ を最大とする $\alpha^{*}$ は, $\frac{\mathrm{d}}{\mathrm{d} \alpha} f(\alpha)=0$ から

$$
\sin \alpha^{*}=\frac{1}{2}
$$

つまり，仰角が $\alpha^{*}=\frac{\pi}{6}\left(=30^{\circ}\right)$ の時に両者の差は最も大きくなる. $f\left(\frac{\pi}{6}\right)=\frac{1}{4}$ から, 差の上限値は 0.25 となる.

この結果は, 天空率算定図から近似的に求めた天空率と天空比と の差が 0.25 以内であるという数值 ${ }^{4) 5) 6) 20)}$ と矛盾しない.

次に, 天空率と天空比との差が 0 から最大である 0.25 まで連続 的に拡大する建物形状を示す．四 4 のように，円形広場を囲む仰角 $\alpha$, 水平角 $\beta$ の円錁建物を考える. 広場の中央地点で測定すると仮 定する. 式 (3) から推察できるように, 天空率と天空比との差は,

$$
f(\alpha, \beta)=\frac{\beta}{2 \pi} \sin \alpha(1-\sin \alpha)
$$

で与元られる. 建物が広場を完全に一周する場合 $(\beta=2 \pi)$ ，

$$
f(\alpha, 2 \pi)=\sin \alpha(1-\sin \alpha)
$$

となり, 差 $f(\alpha, 2 \pi)$ は仰角 $\alpha$ の関数として, 図 5 のようになる. 繸 軸では天空率 $\sigma$, 天空比 $\omega$ を実線にて, それらの差 $f(\alpha, 2 \pi)$ を点 線にて示す. 雨者の差は $0\left(\alpha=0^{\circ}\right.$ もしくは $\left.\alpha=90^{\circ}\right)$ から 0.25 $\left(\alpha=30^{\circ}\right)$ まで開くことが確認できる. また，仰角を $\alpha=30^{\circ}$ と した場合, 式 (5) から

$$
f\left(\frac{\pi}{6}, \beta\right)=\frac{\beta}{8 \pi}
$$

となる. 水平角 $\beta$ とともに, 両者の差が $0\left(\beta=0^{\circ}\right)$ から 0.25 $\left(\beta=360^{\circ}\right)$ まで線形で増加することも分かる. 天空率と天空比と の差が常に一定の割合ではなく，仰角や水平角によってその差はか なり異なり，最大 0.25 までに達することが分かる.

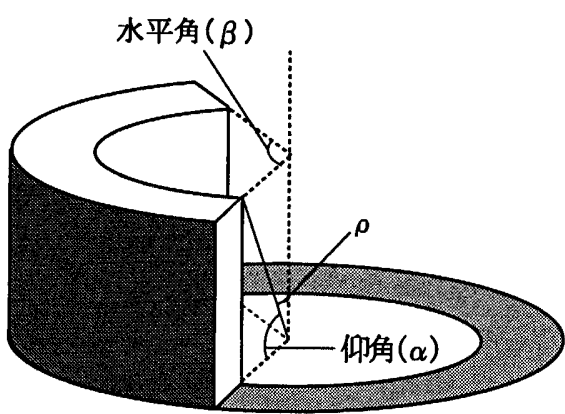

図 4 円環建物

$\sigma, \omega$

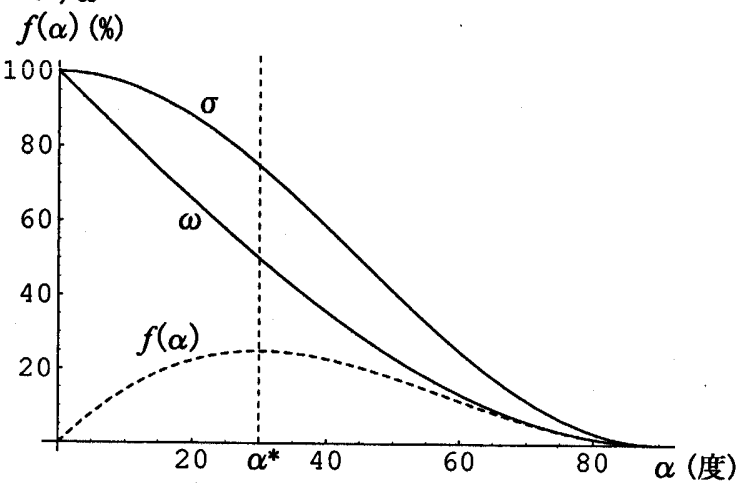

図 5 仰角 $\alpha$ と天空率 $\sigma$ と天空比 $\omega$ との差 $(\beta=2 \pi)$

\section{3 直方体建物での鼓価}

\section{1 天空率と天空比}

ここでは, 図 6 のように, 幅員 $r(>0)$ の直線道路に沿って建つ 間口 $w(>0)$, 高さ $h(>0)$ の直方体建物を考える. 建物中央の道 路反対側地点で天空率や天空比を測定するものとする. 測定地点か ら建物中央屋上への仰角を $\alpha$ と定義する．すなわち，

$$
\sin \alpha \equiv \frac{h}{\sqrt{r^{2}+h^{2}}} .
$$

また, 測定地点から建物両端への水平角を $\beta$ とし, その半分の角度 （建物中央と建物端部との間の水平角）を $\beta^{\prime}$ と定義する. つまり，

$$
\sin \frac{\beta}{2} \equiv \sin \beta^{\prime} \equiv \frac{w}{2 \sqrt{r^{2}+\left(\frac{w}{2}\right)^{2}}} .
$$

なお，街路プロポーション指標である幅員・高さ比 $(\mathrm{D} / \mathrm{H})$ や間 口・幅員比 (W/D) は, $\frac{r}{h}\left(=\frac{1}{\tan \alpha}\right), \frac{w}{r}\left(=2 \tan \beta^{\prime}\right)$ となる ${ }^{24) 25)}$.

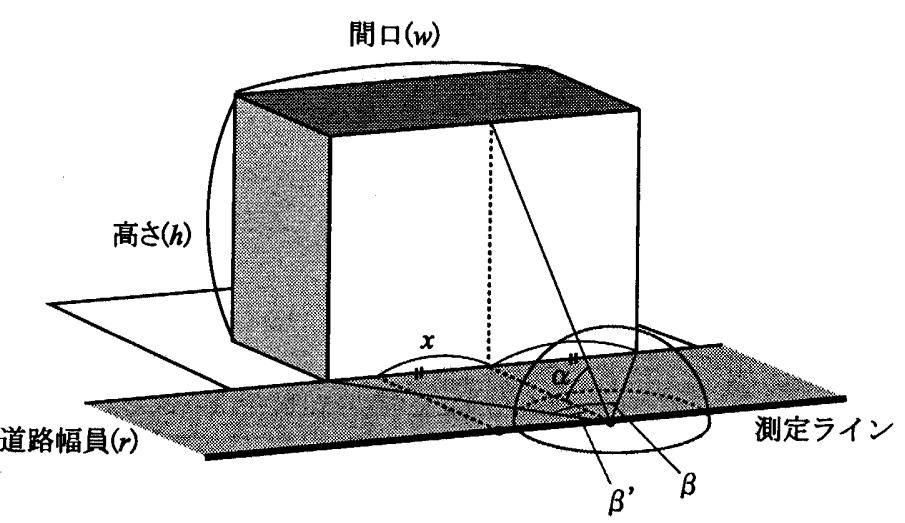

図 6 直方体建物

ここから，直方体建物に対する天空率や天空比を計算する．なお， 天空比は立体角の結果からも計算できる ${ }^{8)}$ 。 天空率は面積分公式か らも導出できる26).ここでは, 球面三角形幾何学公式を用い天空比, 天空率と逐次に直接導出するので, これらの証明方法とは異なる.

最初に天空比 $\omega$ を求める. $P_{R}\left(P_{L}, P_{T}\right)$ を, 建物の右側面（左 側面，屋上面）之測定地点から定まる平面， $P_{G}$ を地表面とする. つ まり，図 7 のように測定位置を $\mathbf{o}$ とすると, $P_{R}$ は 3 点 $\mathbf{o}, \mathbf{q}_{1}, \mathbf{q}_{2}$, $P_{T}$ は 3 点 $\mathrm{o}, \mathrm{q}_{2}, \mathrm{q}_{3}, P_{L}$ は 3 点 $\mathrm{o}, \mathrm{q}_{3}, \mathrm{q}_{4}, P_{G}$ は 3 点 $\mathrm{o}, \mathrm{q}_{4}$, $\mathbf{q}_{1}$ をそれぞれ通る.

建物は垂直に立つので, $P_{R}$ 及び $P_{L}$ は地表面 $P_{G}$ 之直交する. 平面 $P_{R}$ 及び $P_{T}$ との二面角度を計算するために, 直交座標系を導 入する. 原点を $\mathrm{o}, x$ 軸（ $y$ 軸）を建物側面（前面）壁面線と平行 に, $z$ 軸を天空方向とする. すると, 平面 $P_{T}$ は $x-y$ 平面を $y$ 軸 周りに角度 $\alpha$ だけ回転させたもの, 平面 $P_{R}$ は $x-z$ 平面を $z$ 軸 周りに角度 $\beta^{\prime}$ だけ回転させたものである. よって, 平面 $P_{R}, P_{T}$ の単位法線ベクトルは, $\left(\sin \beta^{\prime}, \cos \beta^{\prime}, 0\right),(\sin \alpha, 0, \cos \alpha)$ と なる. したがって, 平面 $P_{R}$ と $P_{T}$ とがなす二面角度 $\varphi$ は, これら ベクトルの内積から, $\cos \varphi=\sin \alpha \sin \beta^{\prime}$ となる. $\varphi \geq \frac{\pi}{2}$ なので,

$$
\varphi=\pi-\arccos \left(\sin \alpha \sin \beta^{\prime}\right) .
$$

対称性から, 平面 $P_{T}$ 及び $P_{L}$ とがなす二面角度も $\varphi$ と一致する.

平面 $P_{R}, P_{L}, P_{T}$ 及び $P_{G}$ の軌跡は想定半球面にて大円 ${ }^{23) 27) 28)}$ として表れ,これら軌跡から定義される球面四角形が建物の投影部 
分へ対応する. なお, 平面 $P_{R}, P_{L}$ が生成する大円は方位円と㭔 ばれる2). 想定半球が単位半球であると仮定できるので, 球面四角 形の表面積は，球面多角形の公式23)27)28)から，

$$
\begin{aligned}
\frac{\pi}{2}+\frac{\pi}{2}+\varphi+\varphi-2 \pi & =\pi-2 \arccos \left(\sin \alpha \sin \beta^{\prime}\right) \\
& =2 \arcsin \left(\sin \alpha \sin \beta^{\prime}\right)
\end{aligned}
$$

となる. 単位半球の表面積は $2 \pi$ であるから, 天空比 $\omega$ は,

$$
\omega=1-\frac{\arcsin \left(\sin \alpha \sin \beta^{\prime}\right)}{\pi} .
$$

次に, 天空率 $\sigma$ を求める. 図 8 は想定半球の水平投影図である. 陰影を施した領域のように，建物は楕円 $\frac{x^{2}}{\cos ^{2} \alpha}+y^{2}=1$ (平面 $P_{T}$ に対応), 円 $x^{2}+y^{2}=1$ (平面 $P_{G}$ に対応) 及び二本の直線 $y=\tan \beta^{\prime} x$ (平面 $P_{L}$ へ対応) 及び $y=-\tan \beta^{\prime} x$ (平面 $P_{R}$ へ 对応）で囲まれた領域へ正射影される. 角度 $2 \beta^{\prime}$ の扇型の面積は $\beta^{\prime}$ であるから，この領域の面積は， $x=u \cos \alpha \cos \theta$ 及び $y=u \sin \theta$ とし極座標変換（変数 $x, y$ から変数 $u, \theta$ への変換）から,

$$
\begin{aligned}
& \beta^{\prime}-\iint_{\frac{x^{2}}{\cos ^{2} \alpha}+y^{2} \leq 1, y \geq \tan \beta^{\prime} x, y \leq-\tan \beta^{\prime} x} \mathrm{~d} x \mathrm{~d} y \\
= & \beta^{\prime}-2 \int_{0}^{\arctan \left(\tan \beta^{\prime} \cos \alpha\right)} \int_{0}^{1} u \cos \alpha \mathrm{d} u \mathrm{~d} \theta \\
= & \beta^{\prime}-\cos \alpha \arctan \left(\cos \alpha \tan \beta^{\prime}\right) .
\end{aligned}
$$

単位円の面積は $\pi$ であるから, 天空率 $\sigma$ は,

$$
\sigma=1-\frac{\beta^{\prime}-\cos \alpha \arctan \left(\cos \alpha \tan \beta^{\prime}\right)}{\pi} .
$$

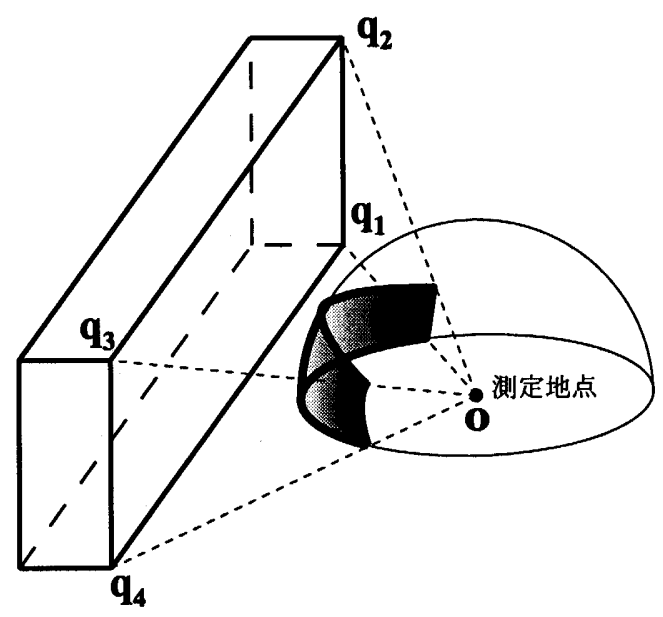

图 7 平面の定義と球面四角形

無限高さ建物 $\left(\alpha=\frac{\pi}{2}\right)$ では, $\beta=2 \beta^{\prime}$ に注意すると,

$$
\omega=1-\frac{\beta}{2 \pi}, \quad \sigma=1-\frac{\beta}{2 \pi}
$$

と両者は一致するが, 無限間口建物 $(\beta=\pi)$ では,

$$
\omega=1-\frac{\alpha}{\pi}, \quad \sigma=1-\frac{1-\cos \alpha}{2}
$$

となり, 両者は一致しない. なお, 無限高さ建物 $\left(\alpha=\frac{\pi}{2}\right)$ 及び無 限間口建物 $(\beta=\pi)$ では, 想定半球面上の建物投影部分は角度 $\beta$ の月形 (球面二辺形) ${ }^{27)}$ の半分, 角度 $\alpha$ の月形 ${ }^{13)}$ とそれぞれ一致 する. この解积と式 (8) 及び式 (9) の天空比 $\omega$ とは整合している.

式（6）から, 天空比 $\omega$ では仰角 $\alpha$ に比べて水平角 $\beta$ は半分し か効いていない. これは, 図 6 からも分かるように, 水平方向では

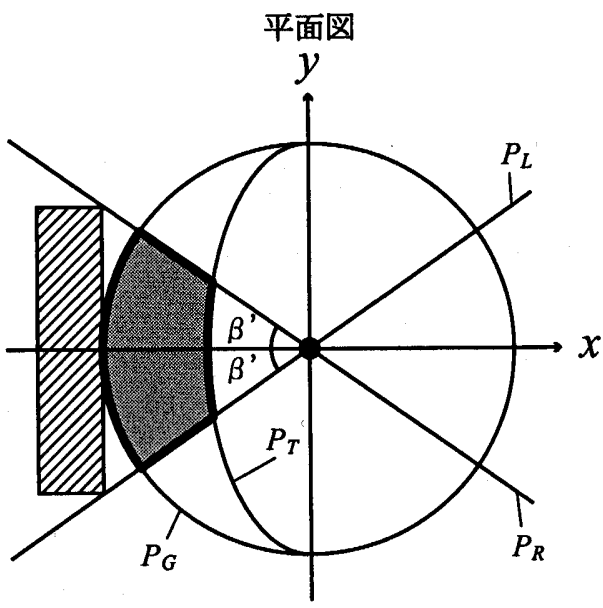

図 8 球面四角形の正射影

建物中点, 鈶直方向では建物端点で計測しているためである. 言い 換えると, 半球を鈶直方向に二つの四半球へ分割すると, 対称性か ら半球での天空比は四半球での天空比に等しくなる.こうして, 仰 角 $\alpha$ と水平角 $\beta$ の半分 $\beta^{\prime}$ は天空比 $\omega$ に同等の影響を与えること となる. 対照的に，垂直方向の正投影から計算される天空率 $\sigma$ は， 一方向からの投影であり，仰角 $\alpha$ と水平角 $\beta$ への影響は異なる.

水平角を $\beta=30^{\circ}(\mathrm{W} / \mathrm{D} \approx 0.536), \beta=60^{\circ}(\mathrm{W} / \mathrm{D} \approx 1.155)$ とし, 仰角 $\alpha$ を変化させたときの天空率 $\sigma$ 及び天空比 $\omega$ を, 図 9

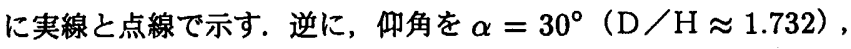
$\alpha=60^{\circ}(\mathrm{D} / \mathrm{H} \approx 0.577)$ とし，水平角 $\beta$ を変化させたときの天 空率 $\sigma$ 及び天空比 $\omega$ を, 図 10 に実線と点線で示す.

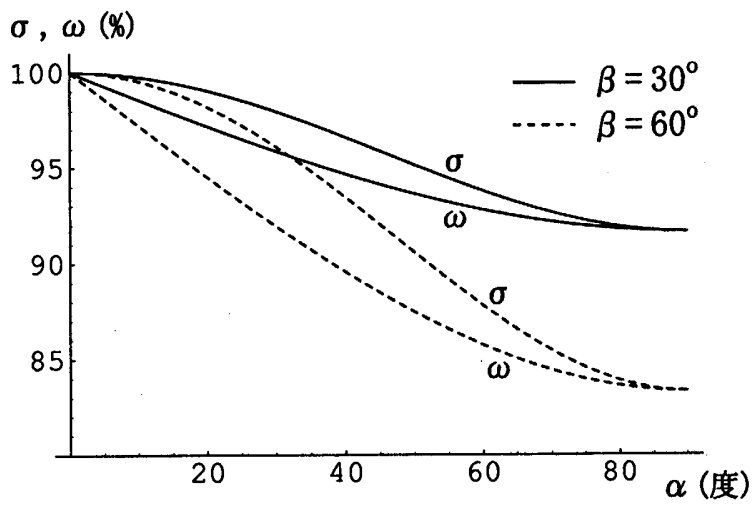

图 9 仰角 $\alpha$ と天空率 $\sigma \cdot$ 天空比 $\omega$

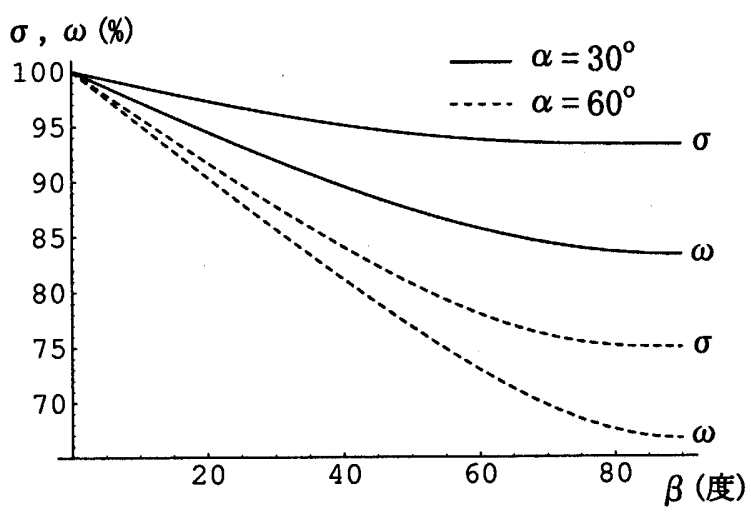

图 10 水平角 $\beta$ と天空率 $\sigma \cdot$ 天空比 $\omega$ 


\section{2 仰角, 水平角の影整}

式（6）と式（7）から，差 $f(\alpha, \beta) \equiv \sigma-\omega$ を求めると, $\underline{\arcsin \left(\sin \alpha \sin \beta^{\prime}\right)+\cos \alpha \arctan \left(\cos \alpha \tan \beta^{\prime}\right)-\beta^{\prime}}$

となる. 最初に, 仰角 $\alpha$ を固定し水平角の影響を分析しよう. 図 10 では, 特定の仰角に対し水平角 $\beta$ の増加とともに, 天空比 $\omega$ と 天空率 $\sigma$ との差は大きくなった，この性質は，以下の命題に示すよ う, どのような仰角 $\alpha$ に対しても成立する。

命題 3 どのような仰角 $\alpha\left(0<\alpha<\frac{\pi}{2}\right)$ に対しても, 水平角 $\beta$ が大 きくなるにつれて両指標はさらに開く.つまり， $\beta_{1}>\beta_{2}$ ならば,

$$
f\left(\alpha, \beta_{1}\right)>f\left(\alpha, \beta_{2}\right)
$$

証明 : $f(\alpha, \beta)$ について水平角 $\beta^{\prime}$ に関する偏導関数 $f_{\beta^{\prime}}$ は,

$$
\begin{aligned}
\pi f_{\beta^{\prime}} & =\frac{\sin \alpha \cos \beta^{\prime}}{\sqrt{1-\sin ^{2} \alpha \sin ^{2} \beta^{\prime}}}+\frac{\cos ^{2} \alpha}{\cos ^{2} \beta^{\prime}+\cos ^{2} \alpha \sin ^{2} \beta^{\prime}}-1 \\
& =\frac{\sin \alpha \cos \beta^{\prime}}{\sqrt{1-\sin ^{2} \alpha \sin ^{2} \beta^{\prime}}}-\frac{\sin ^{2} \alpha \cos ^{2} \beta^{\prime}}{1-\sin ^{2} \alpha \sin ^{2} \beta^{\prime}} .
\end{aligned}
$$

ここで, $\frac{\sin ^{2} \alpha \cos ^{2} \beta^{\prime}}{1-\sin ^{2} \alpha \sin ^{2} \beta^{\prime}}<\frac{\sin ^{2} \alpha \cos ^{2} \beta^{\prime}}{\sin ^{2} \alpha-\sin ^{2} \alpha \sin ^{2} \beta^{\prime}}=1$ から，第二項は 1 以下となる．第一項は第二項の平方根であるから，第一項が第二 項より大きくなり， $f_{\beta^{\prime}}>0$ となる. こうして, $f(\alpha, \beta)$ が水平角 $\beta^{\prime}$ の増加関数になることが分かる.

命題 3 は次のように解釈できる. 天空からの正射影は各方位角 ごとに差異を発生させる. その差異は, 命題 1 から同符号である. よって, 水平角度増加とともにその差異が累積される.

次に, 水平角 $\beta$ を固定し仰角の影響を分析しよう. 図 9 では, 特 定の水平角に対し， $\alpha=35^{\circ}$ 前後までは，仰角 $\alpha$ の增加とともに 天空比と天空率との差が開き，その後狭まった. つまり，両者の差 は $\alpha=35^{\circ}$ 前後で最大となる単峰の関数であった. この性質は, 次 の命題が示すように, どのような水平角についても成り立つ.

命題 4 どのような水平角 $\beta(0<\beta<\pi)$ に対しても，両指標が最 も開く仰角 $\alpha^{*}$ は,

$$
\frac{1}{2} \leq \sin \alpha^{*} \leq \frac{2}{\pi}
$$

証明 : $g \equiv \frac{\mathrm{d}}{\mathrm{d} \alpha} \arcsin \left(\sin \alpha \sin \beta^{\prime}\right)$ と定義すると，

$$
g=\frac{\cos \alpha \tan \beta^{\prime}}{\sqrt{1+\cos ^{2} \alpha \tan ^{2} \beta^{\prime}}} .
$$

この式から,

$$
\begin{aligned}
& \arcsin (g)=\arctan \left(\cos \alpha \tan \beta^{\prime}\right) \\
& \frac{g}{\sqrt{1-g^{2}}}=\cos \alpha \tan \beta^{\prime} .
\end{aligned}
$$

さらに, $g_{\alpha} \equiv \frac{\mathrm{d} g}{\mathrm{~d} \alpha}, g_{\beta^{\prime}} \equiv \frac{\mathrm{d} g}{\mathrm{~d} \beta^{\prime}}$ と定義すると, 式 (12) から

$$
\begin{aligned}
& \frac{g_{\alpha}}{\sqrt{1-g^{2}}}=-\sin \alpha \tan \beta^{\prime}\left(1-g^{2}\right), \\
& \frac{g_{\beta^{\prime}}}{\sqrt{1-g^{2}}}=\frac{\cos \alpha}{\cos ^{2} \beta^{\prime}}\left(1-g^{2}\right) .
\end{aligned}
$$

式 (10) で示されている $f(\alpha, \beta)$ に対し， $f_{\alpha}$ 及び $f_{\alpha \alpha}$ を仰角 $\alpha$ に関する偏導関数及び第二次偏導関数とする. $f_{\alpha}=0$ を満たす $\alpha$ に対して， $f_{\alpha \alpha}<0$ を証明しよう. 式 (11), (12) 及び (13) を用 いて,

$$
\begin{aligned}
\pi f_{\alpha} & =g+\cos \alpha \frac{g_{\alpha}}{\sqrt{1-g^{2}}}-\sin \alpha \arcsin (g) \\
& =g-\frac{\tan \alpha}{\tan \beta^{\prime}} g^{2}-\sin \alpha \arcsin (g)
\end{aligned}
$$

$$
\begin{aligned}
\pi f_{\alpha \alpha}= & \left(1-2 \frac{\tan \alpha}{\tan \beta^{\prime}} g\right) g_{\alpha}-\frac{1}{\cos ^{2} \alpha \tan \beta^{\prime}} g^{2} \\
& -\sin \alpha \frac{g_{\alpha}}{\sqrt{1-g^{2}}}-\cos \alpha \arcsin (g) \\
= & \left(1-2 \frac{\tan \alpha}{\tan \beta^{\prime}} g\right) g_{\alpha}-\frac{1}{\tan \beta^{\prime}} g^{2}-\cos \alpha \arcsin (g) .
\end{aligned}
$$

ここで, $f_{\alpha}=0$ 及び $\arcsin (g)>g$ に注意して,

$$
\begin{aligned}
1-2 \frac{\tan \alpha}{\tan \beta^{\prime}} g & =\frac{1}{g}\left(\sin \alpha \arcsin (g)-\frac{\tan \alpha}{\tan \beta^{\prime}} g^{2}\right) \\
& >\frac{1}{g}\left(\sin \alpha g-\frac{\tan \alpha}{\tan \beta^{\prime}} g^{2}\right) \\
& =\sin \alpha\left(1-\frac{1}{\cos \alpha \tan \beta^{\prime}} g\right)>0 .
\end{aligned}
$$

式 (13) から $g_{\alpha}<0$ となるから, 結局 $f_{\alpha \alpha}<0$ となる. $f(\alpha, \beta)$ は仰角 $\alpha$ に関して凸関数, つまり単峰であることが導けた．このよ うに，どのような水平角 $\beta$ に対しても， $f_{\alpha}=0$ の解が $\alpha^{*}$ となる. 陰関数定理 ${ }^{29)}$ を用いると, $f_{\alpha}=0$ を満たす $\alpha, \beta$ に関して,

$$
\frac{\mathrm{d} \alpha}{\mathrm{d} \beta^{\prime}}=-\frac{f_{\alpha \beta^{\prime}}}{f_{\alpha \alpha}}
$$

ただし， $f_{\alpha \beta^{\prime}} \equiv \frac{\mathrm{d}}{\mathrm{d} \beta^{\prime}} f_{\alpha}$ である.ここでは, $\frac{\mathrm{d} \alpha}{\mathrm{d} \beta^{\prime}}>0$ を証明しよ う. 式 (12) 及び (14) を用いて,

$$
\begin{aligned}
f_{\alpha \beta^{\prime}} & =\left(1-2 \frac{\tan \alpha}{\tan \beta^{\prime}} g\right) g_{\beta^{\prime}}+\frac{\tan \alpha}{\sin \beta^{\prime 2}} g^{2}-\sin \alpha \frac{g_{\beta^{\prime}}}{\sqrt{1-g^{2}}} \\
& =\left(1-2 \frac{\tan \alpha}{\tan \beta^{\prime}} g\right) g_{\beta^{\prime}} .
\end{aligned}
$$

式 (14) から $g_{\beta^{\prime}}>0$ となり, 不等式 (15) を用いて, $f_{\alpha \beta^{\prime}}>0$ と なる. この結果, $f_{\alpha \alpha}<0$ と合わせ, 式 (16) から $\frac{\mathrm{d} \alpha}{\mathrm{d} \beta^{\prime}}>0$ とな る. したがって, $f_{\alpha}=0$ の解 $\alpha^{*}$ は $\beta$ の增加とともに大きくなる. こうして, 任意の $\beta$ に対する $f_{\alpha}=0$ の解 $\alpha^{*}$ は, $\beta^{\prime} \approx 0$ の解 $\alpha^{*}$ より大きく, $\beta=\pi$ の解 $\alpha^{*}$ より小さくなる.

ここで, $\beta=\pi$ の場合, $g(\alpha, \pi)=1$ となるので, $f_{\alpha}=0$ から, $\sin \alpha^{*}=\frac{2}{\pi}$ となる. また,

$$
\pi \frac{f_{\alpha}}{\beta^{\prime}}=\frac{g}{\beta^{\prime}}-\tan \alpha \cos \beta^{\prime} \frac{\beta^{\prime}}{\sin \beta^{\prime}} \frac{g^{2}}{\beta^{\prime 2}}-\sin \alpha \frac{\arcsin (g)}{\beta^{\prime}} .
$$

$\lim _{\beta^{\prime} \rightarrow 0} \frac{\beta^{\prime}}{\sin \beta^{\prime}}=1, \lim _{\beta^{\prime} \rightarrow 0} \frac{g}{\beta^{\prime}}=\cos \alpha, \lim _{\beta^{\prime} \rightarrow 0} \cos \beta^{\prime}=$ 1, ロピタルの定理 ${ }^{29)}$ と式 (14) を用いて, $\lim _{\beta^{\prime} \rightarrow 0} \frac{\arcsin (g)}{\beta^{\prime}}=$ $\lim _{\beta^{\prime} \rightarrow 0} \frac{g_{\beta^{\prime}}}{\sqrt{1-g^{2}}}=\cos \alpha$ となり,

$$
\lim _{\beta^{\prime} \rightarrow 0} \pi \frac{f_{\alpha}}{\beta^{\prime}}=\cos \alpha-\tan \alpha \cos ^{2} \alpha-\sin \alpha \cos \alpha .
$$

$\lim _{\beta^{\prime} \rightarrow 0} \frac{f_{\alpha}}{\beta^{\prime}}=0$ から $\sin \alpha^{*}=\frac{1}{2}$ となる（これは式 (4) と一致す る). 以上を総括すると, $\frac{1}{2} \leq \sin \alpha^{*} \leq \frac{2}{\pi}$ となる. 
差が最大となる仰角を具体的に求めてみよう. 非線形方程式 $f_{\alpha^{*}}=$ 0 を满たす仰角 $\alpha^{*}$ を数值計算で求めその時の相違 $f\left(\alpha^{*}, \beta\right)$ を計 算した. 仰角 $\alpha^{*}$ を実線, 差 $f\left(\alpha^{*}, \beta\right)$ を点線にてそれぞれ水平角 $\beta(0<\beta<\pi)$ の関数で図 11 に示す. ただし, 左側䋛軸は $\alpha^{*}$ の 値を，右側絣軸は $f\left(\alpha^{*}, \beta\right)$ の值を表す。

命題 4 から, 仰角 $\frac{\pi}{6}\left(=30^{\circ}\right) \leq \alpha^{*} \leq \arcsin \left(\frac{2}{\pi}\right)\left(\approx 39.54^{\circ}\right)$ であり、このことは, 図 11 からも確認できる.これらの值は, 1 $.732 \leq \mathrm{D} / \mathrm{H} \leq 1.211$ に対応する. 日本における道路沿い建物の 多くはこれらの值をとるが，このような典型的な状況で両者の食い 違いは最も大きくなる.したがって，これらの建物では，天空率は 高くても，天空比は必ずしも大きくならないことが分かる．なお， 差 $f(\alpha, \beta)$ が仰角 $\alpha$ に関して連続で単峰であるから， $\alpha^{*}$ 周辺での 仰角でも両者の靟離幅は大きい。

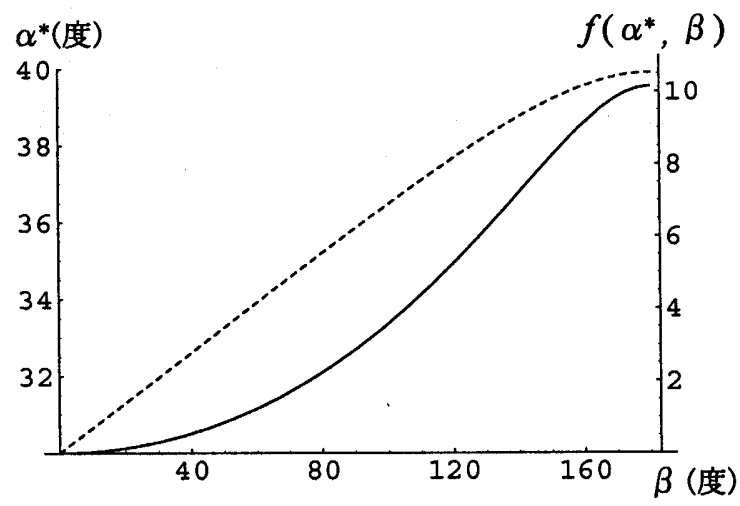

図 11 仰角 $\alpha^{*}$ と最大差 $f\left(\alpha^{*}, \beta\right)$

\section{3 測定位置の影觜}

図 6 でも示されているように，測定地点を建物中央前に固定しこ れまで分析を進めてきた．測定地点を，図 6 に定義された道路沿い の測定ライン上に沿って建物端部方向へ変化させたときの天空率や 天空比の変化を求めてみよう.

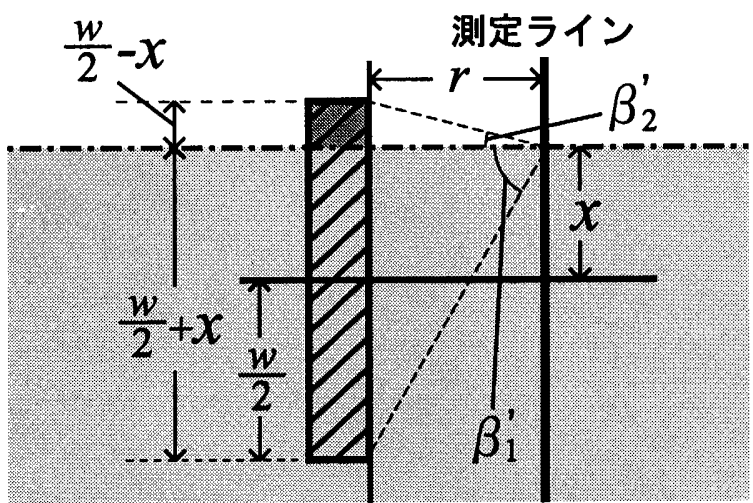

図 12 天空率・天空比の算出方法

建物中央からの仰角が $\alpha$ 水平角が $\beta$ となるような建物について， 建物中央から距離 $x$ だけ離れた場所で測定した天空率や天空比を，そ れぞれ $\sigma(x: \alpha, \beta), \omega(x: \alpha, \beta)$ とする. 図 12 のように, この測定地 点を通り，測定ラインと直交する直線（図中の一転鎖線）で二つの半 空間に分解する. $\beta_{1} \equiv 2 \arctan \left(\frac{w+2 x}{2 r}\right), \beta_{2} \equiv 2 \arctan \left(\frac{w-2 x}{2 r}\right)$ とすると，陰影を施した半空間での天空率は $\sigma\left(0: \alpha, \beta_{1}\right)$, もう一
方の半空間での天空率は $\sigma\left(0: \alpha, \beta_{2}\right)$ となる. 図 12 からも理解で きるように,これらの平均が, 天空率 $\sigma(x: \alpha, \beta)$ となる. 同様に, 天空比 $\omega(x: \alpha, \beta)$ も表現できる.このように,

$$
\begin{aligned}
& \sigma(x: \alpha, \beta)=\frac{1}{2} \sigma\left(0: \alpha, \beta_{1}\right)+\frac{1}{2} \sigma\left(0: \alpha, \beta_{2}\right), \\
& \omega(x: \alpha, \beta)=\frac{1}{2} \omega\left(0: \alpha, \beta_{1}\right)+\frac{1}{2} \omega\left(0: \alpha, \beta_{2}\right),
\end{aligned}
$$

となる. 天空比 $\omega\left(0: \alpha, \beta_{1}\right), \omega\left(0: \alpha, \beta_{2}\right)$ や天空率 $\sigma\left(0: \alpha, \beta_{1}\right)$, $\sigma\left(0: \alpha, \beta_{2}\right)$ は式（6）や式（7）で与えられている.したがって, 建物中央から距離 $x$ 離れた測定地点における両指標の開き $f(x$ : $\alpha, \beta) \equiv \sigma(x: \alpha, \beta)-\omega(x: \alpha, \beta)$ も解析的に導出できる.

命題 5 両指標が最も開く測定位置は建物中央である.つまり，ど の仰角 $\alpha\left(0<\alpha<\frac{\pi}{2}\right)$ 及び水平角 $\beta(0<\beta<\pi)$ に対しても，

$$
f(0: \alpha, \beta)>f(x: \alpha, \beta), \quad(x \neq 0) .
$$

証明 : $f(x: \alpha, \beta)$ の測定位置 $x$ に関する導関数は,

$$
\begin{aligned}
& \pi \frac{\mathrm{d}}{\mathrm{d} x} f(x: \alpha, \beta) \\
= & \frac{1}{2}\left(\frac{\mathrm{d}}{\mathrm{d} x} f\left(\alpha, \beta_{1}\right)+\frac{\mathrm{d}}{\mathrm{d} x} f\left(\alpha, \beta_{2}\right)\right) \\
= & \frac{1}{2 r} f_{\beta^{\prime}}\left(\frac{1}{1+\left(\frac{w+2 x}{2 r}\right)^{2}}-\frac{1}{1+\left(\frac{w-2 x}{2 r}\right)^{2}}\right) .
\end{aligned}
$$

命題 3 から $f_{\beta^{\prime}}>0$, また $\frac{w+2 x}{2 r}>\frac{w-2 x}{2 r}$ から括弧内は負となる. したがって, $\frac{\mathrm{d}}{\mathrm{d} x} f(x: \alpha, \beta)<0$ となる. こうして, 任意の $\alpha$ 及び $\beta$ に対し $f(x: \alpha, \beta)$ は $x$ に関して単調減少することが分かる.

図 13 に水平角 $\beta=60^{\circ}$ と固定し, 仰角 $\alpha=30^{\circ}(\mathrm{D} / \mathrm{H}$ $=\sqrt{3} \approx 1.732 ）$ の天空率と天空比を実線で, 仰角 $\alpha=45^{\circ}$ （D／

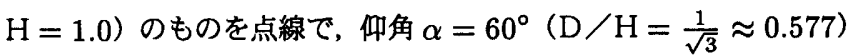
の結果を一点鎖線でそれぞれ示す. 測定地点が建物中央から建物端 部へ移動するにつれてどの仰角でも，天空率や天空比の増加する様 子が確認できる. また, 天空率と天空比との乘離が, どの仰角でも 建物中央 $x=0$ で最も大きいことも分かる.

天空率規制における測定地点は, 測定ライン上数箇所に等間隔で 設定される，建物中央は，そのうち想定球面に映り込む建物面積が 最大となり最も配虑すべき位置である．命題 5 から，このような場 所では, 天空率という評価値と天空比という評価値とは最も異なる.

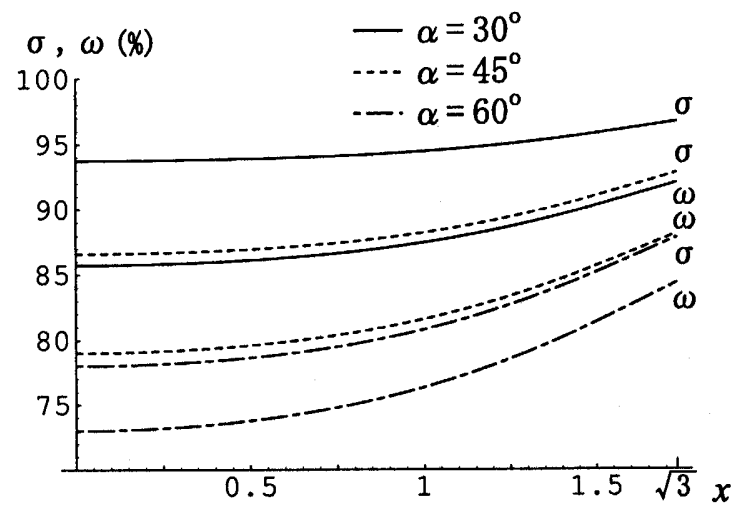

図 13 測定地点と天空率 $\sigma \cdot$ 天空比 $\omega$ 


\section{4 最大差}

測定位置を建物中央前に固定した時の, 乘離 $f(\alpha, \beta)$ を仰角 $\alpha$ 及 び水平角 $\beta$ の関数で 3 次元的に等高線表示したものを図 14 に示す. 等高線の間隔は 0.01 刻みである. 仰角 $\alpha$ 及び水平角 $\beta$ の二軸の関 数で見たとしても， $f(\alpha, \beta)$ が単峰であることが確認できる．この 山頂の值を,これまで導出した命題 3 及び 4 から解析的に求めよ う. なお, 命題 5 から, 測定地点の位置を自由に変えたとしても, この値が值方体建物の最大差となる.

$\alpha$ (度)

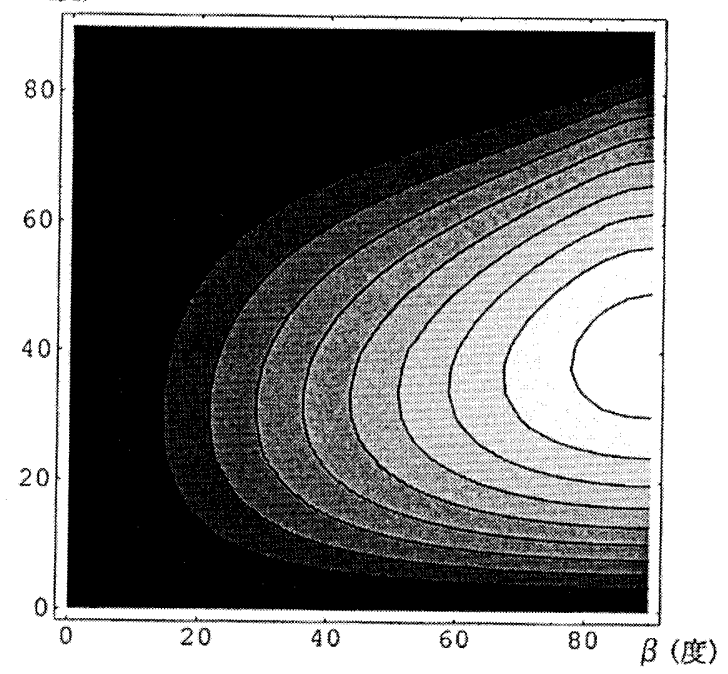

図 14 差 $f(0: \alpha, \beta)$ の等高線

命題 6 最大差は $\frac{\arcsin \left(\frac{2}{\pi}\right)}{\pi}+\frac{\sqrt{\pi^{2}-4}}{2 \pi}-\frac{1}{2}$ である. つまり, ゙゙のよ うな仰角 $\alpha\left(0<\alpha<\frac{\pi}{2}\right)$ 及び水平角 $\beta(0<\beta<\pi)$, どのような測 定位膡 $x(-\infty<x<\infty)$ に対しても,

$$
f(x: \alpha, \beta) \leq \frac{\arcsin \left(\frac{2}{\pi}\right)}{\pi}+\frac{\sqrt{\pi^{2}-4}}{2 \pi}-\frac{1}{2}(\approx 0.1053) .
$$

証明 : 命題 5 から $f(x: \alpha, \beta) \leq f(0: \alpha, \beta)$ である. また, 命題 3 及び命題 4 から, 測定位置が建物正面では, $\beta=\pi, \sin \alpha=\frac{2}{\pi}$ の時に差が最大となるから， $f(0: \alpha, \beta) \leq f\left(\arcsin \left(\frac{2}{\pi}\right), \pi\right)$ であ る. したがって, $f\left(\arcsin \left(\frac{2}{\pi}\right), \pi\right)$ が最大差となる. 式 $(10)$ にて, $\cos \left(\arcsin \left(\frac{2}{\pi}\right)\right)=\cos \left(\arccos \left(\sqrt{1-\frac{4}{\pi^{2}}}\right)\right)=\sqrt{1-\frac{4}{\pi^{2}}}$ に注意 して,

$$
\begin{aligned}
f\left(\arcsin \left(\frac{2}{\pi}\right), \pi\right) & =\frac{\arcsin \left(\frac{2}{\pi}\right)+\cos \left(\arcsin \left(\frac{2}{\pi}\right)\right) \frac{\pi}{2}-\frac{\pi}{2}}{\pi} \\
& =\frac{\arcsin \left(\frac{2}{\pi}\right)}{\pi}+\frac{\sqrt{\pi^{2}-4}}{2 \pi}-\frac{1}{2}
\end{aligned}
$$

命題 6 から, 天空率と天空比との差は最大で 0.11 までに達する ことが分かる．この結果は，図 14 と整合している，したがって，天 空率から值 0.11 を引けば, 天空比の安全側を保証する数値となる.

なお，命題 2 は建物形状を限定しないより一般的な仮定の下で導 出した. この結果と比べると, 最大差が 0.25 から 0.11 までかなり 小さくなる．これは，直方体建物では各方位角ごとに建物屋上への 仰角が異なり，差異が大きくなる方位角と小さくなる方位角とが混 在するからだと解釈できる.

\section{4 まとめ}

2003 年に導入された天空率規制により，天空率指標が注目を浴 びている. 一方で, 球面に映り込んだ天空部分の空比率である天空 比は, 天空率とともに採光や開放感を表現する環境指標である.し たがって，両者は指標目標も計算方法も互いに強く関連する.

本研究では，第一に，どのような建物形状どのような測定位置で も，天空率が天空比を常に上回ることを示した．したがって，天空 率は天空比の上限を与え, 逆に, 天空比は天空率を最低保障する. また, 両者の最大差が 0.25 となることを導いた，第二に，直方体 建物に限定すると, 両指標が最も開く建物屋上への仰角は $30^{\circ}$ から $40^{\circ}$ であること，両者が最も開く測定位置は建物中央正面であるこ と, そして, 両者の乘離が最大で 0.11 になることを導出した

これらの結果は, 数值計算ではなく解析的に導出した. 天空率と 天空比という環境指標の数値を解釈する上で参考となるであろう.

\section{考文献}

1）都市構造改革研究会編 : 都市再生と新たな街づくり事業手法マニュアル，エク スナレッジ, 2003

2）菅原澌一：改正建策基淮法 (第 56 条第 7 項) 天空率制度利用から計画技法 まで, 生活産業研究所株式会社, 2004

3）小木曾定彰 : 地域の開放性に関する平均㻎境の理論 その 1 , 建策学会論文報 告集, 182, pp.33-39, 1971

4) 小木曾定彰 : 都市の中の日照, コロナ社, 1972

5) 日本建策学会：日照の湘定と検討，彰国社, 1977

6) 日本建築学会 : 建築設計資料集成一環境，丸善，1978

7）西安男，小島武男，比嘉俊太郎，岡本俊二：一般形態の立体角の図上計算に ついて，建策学会論文報告集，228，pp.73-81, 1975

8）西安男, 小島武男, 比嘉俊太郎, 岡本俊二 : 幾何学的に简単な形萔の立体角 の計算，建築学会論文報告集，229, pp.93-100, 1975

9) 図解住居学編集委員会 : 住まいの㻴境, 榇国社, 1998

10）武井正昭：建築群密集状態の判定手段に関する研究 第 1 部, 建策学会論文報 告集, $162, \mathrm{pp} .43-49,1969$

11）武井正昭：建築群密集状態の判定手段に関する研究 第 2 部，建策学会論文報 告集, $163, \mathrm{pp} .51-61,1969$

12）市川裕通: 街区ユニットの天空率，建築学会計画系論文報告集，423, pp.1-10, 1991.5

13）市川浴通:通りの天空率，建策学会計画系論文報告集，428, pp.29-36, 1991.10

14）市川裕通 : 街区ユニットの天空率その 2 , 建策学会計画系論文報告集，440 pp.1-10, 1992.10

15）市川裕通：街区ユニットの天空率その 3 ，建筑学会計画系論文報告集，472, pp.11-20, 1995.6

16）筷崎道彦. 桑田仁, 斎藤圭 : 建策物周辺の量天時照度比・天空率之晴天時日 射エネルギー比，建筑学会計画系論文集，535，pp.189-196，2000.9

17）桑田仁，徒崎道彦，齐藤圭: 中低層建築物群周辺の最天時照度比・天空率之晴天 時の日射エネルギー比，建策学会計画系論文集，548, pp.177-184, 2001.10

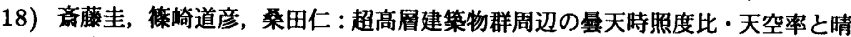
天時の日射エネルギー比, 建筑学会計画系論文集, $565, \mathrm{pp} .201-208,2003.3$

19）齐藤圭，模崎道彦：平均天空率を指標とした性能規定型建策コントロールの 評価シスデム, 建策学会計画系論文集, 575 , pp.101-108, 2003.1

20）西安男，小島武男，比嘉俊太郎，沖 允人，网本 俊二 : 等立体角射影形式の全 天撮影装置の試作，建筑学会論文報告集，245, pp.81-90, 1976

21）沿谷敬一，小林隆史，大澤義明：都市夜景の俯瞰景に関する計量分析-函館市 を対象として-，都市計画学会論文集，39，pp.187-192，2004

22) Y.Ohsawa, H.Kagaya and T.Koshizuka : Map projection errors in the Weber model, Journal of Geographical Systems, 4(3), pp.325342,2002

23）前原润 : 円と球面の幾何学, 朝倉書店, 1998

24）芦原義信：町並みの美学, 岩波書店, 1979

25）芦原義信 : 繶・町並みの美学, 岩波書店, 1983

26）日本建築学会 : 昼光炤明の計算法, 丸善, 1993

27）黒田輤 : 球面数学の基碤, 成山堂書店, 1975

28) Peter Frankl，前原淍 : 幾何学の散步道, 共立出版株式会社, 1997

29）高橋涉：微積分学, 横泜図書, 1999 